\title{
Pengembangan Program Pelatihan Penulisan Modul Untuk Widyaiwara BPSDM Provinsi DKI Jakarta
}

\author{
Putri Purwaning, ${ }^{\square}$ Retno Widyaningrum ${ }^{2}$, Cecep Kustandi 3 \\ ${ }^{1}$ Universitas Negeri Jakarta, Jakarta, Indonesia. \\ ${ }^{2}$ Universitas Negeri Jakarta, Jakarta, Indonesia. \\ 3 Universitas Negeri Jakarta, Jakarta, Indonesia. \\ DOI: https://doi.org/10.21009/JPI.022.04
}

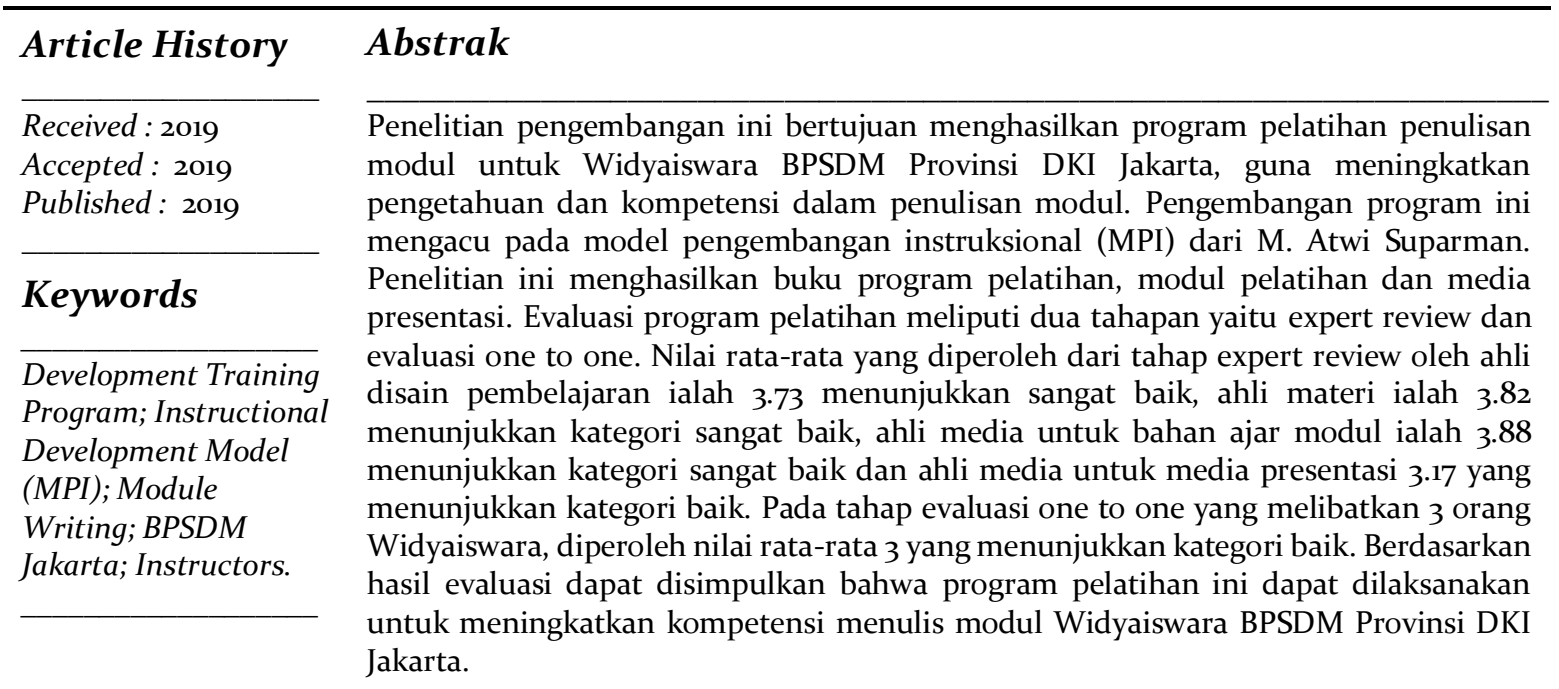

\begin{abstract}
This development research aims to develop an appropriate training program about the module writing which intended to the Instructors of BPSDM Jakarta in order to increase ones' knowledge and competencies in module writing. The program development refers to the Instructional Development Model by M. Atwi Suparman. This research also developed a book of training program for Instructors, training module, and presentation media. The evaluation of the training program includes two phases which consist of expert review and one-to-one evaluation. The evaluation scores from expert review phase by Instructional Design Expert is 3.73 which considered as very good, also the scores from media expert for learning source module is 3.88 which considered as very good and for presentation media 3.17 which considered as very good either. The one-to-one evaluation phase involved 3 Instructors and the scores obtained is 3 which considered as good. Based on the results of evaluation, it can be concluded that this training program is appropriate to be implemented in order to increase the competencies of module writing for the Instructors of BPSDM DKI Jakarta.
\end{abstract}

\footnotetext{
Corresponding author : Putri Purwaning

Adress: Jalan Masjid Al-Amin RToog/Rwoog No.2o Kramat Jati

Jakarta Timur

DKI Jakarta, 13510

E-mail: putripurwaning96@gmail.com
}

(c) 2019 Universitas Negeri Jakarta 


\section{PENDAHULUAN}

Pendidikan dan pelatihan (diklat) merupakan salah satu pendidikan non-formal untuk meningkatkan kualitas Sumber Daya Manusia dalam rangka menghasilkan SDM yang memiliki kompetensi tertentu sesuai dengan kebutuhan organisasi. Diklat diselenggarakan oleh lembaga yang profesional untuk memenuhi kebutuhan kompetensi aparatur yang berguna dalam rangka meningkatkan kinerja baik individu maupun organisasi. Dalam menyelenggarakan diklat harus dilakukan sesuai prosedur yang telah ditetapkan.

Badan Pengembangan Sumber Daya Manusia (BPSDM) Provinsi DKI Jakarta merupakan sebuah badan/institusi yang bertugas mengembangkan Sumber Daya Manusia khususnya Aparatur Sipil Negara di lingkungan Provinsi DKI Jakarta. Dalam mengembangkan kompetensi Aparatur Sipil Negara, BPSDM Provinsi DKI Jakarta menyelenggarakan berbagai jenis pendidikan dan pelatihan. Untuk menyelenggarakan Diklat terdapat komponen yang harus diperhatikan seperti widyaiswara/pengajar, penyelenggara profesional, materi, metode, media pembelajaran, evaluasi serta peserta didik.

Badan Pengembangan Sumber Daya Manusia (BPSDM) Provinsi DKI Jakarta merupakan sebuah badan/institusi yang bertugas mengembangkan Sumber Daya Manusia khususnya Aparatur Sipil Negara di lingkungan Provinsi DKI Jakarta. Dalam mengembangkan kompetensi Aparatur Sipil Negara, BPSDM Provinsi DKI Jakarta menyelenggarakan berbagai jenis pendidikan dan pelatihan. Untuk menyelenggarakan Diklat terdapat komponen yang harus diperhatikan, menurut Hasibuan (2017) komponen yang terdapat dalam pelatihan yaitu tujuan, kurikulum, sarana, peserta, pengajar/pelatih, pelaksanaan.

Demi terwujudnya peningkatan kompetensi Aparatur Sipil Negara di Lingkungan Provinsi DKI Jakarta tentunya BPSDM Provinsi DKI Jakarta harus mempunyai pengajar yaitu Widyaiswara yang berkualitas dan kompeten. Menurut Peraturan Menteri Pendayagunaan Aparatur Negara dan Reformasi Birokrasi No. 22 Tahun 2014, Widyaiswara adalah PNS yang diangkat sebagai pejabat fungsional dengan tugas, tanggung jawab, wewenang, dan hak untuk melakukan kegiatan mendidik, mengajar, dan/atau melatih PNS, Evaluasi dan Pengembangan Diklat pada Lembaga Diklat Pemerintah. Dari pengertian tersebut maka Widyaiswara selain memiliki peran sebagai pengajar, Widyaiswara juga merancang bahan ajar diklat sebagai media pembelajaran yang dibutuhkan untuk mendukung keberlangsungan proses pembelajaran.

Salah satu bahan ajar yang sering digunakan dalam diklat yaitu Modul. Modul adalah bahan belajar yang dirancang secara sistematis berdasarkan kurikulum tertentu dan dikemas dalam bentuk satuan pembelajaran terkecil dan memungkinkan dipelajari secara mandiri dalam satuan waktu tertentu. (Lihat Buku Penyusunan Buku Pelajaran, 2006, 107; Buku Pengembangan Bahan Ajar: Bahan Kuliah Online, 2010, 46; Pedoman Penulisan Pendidikan dan Pelatihan, 2009, 4)

Widyaiswara memiliki tugas sebagai penulis modul yang mampu mengembangkan modul secara kreatif dan tentunya sesuai dengan pedoman yang ada. Adapun kelebihan dan kekurangan yang timbul dengan peran Widyaiwara sebagai penulis modul. Kelebihannya yaitu widyaiswara menguasai materi yang akan dibahas dalam pelatihan, sedangkan kekurangan yaitu tidak memiliki keterampilan dan kemampuan untuk mengembangkan modul seperti penulisan modul yang tidak sesuai standar serta kaidahpenulisan yang baik

Dengan memiliki tugas sebagai pengembang bahan ajar diklat, ditemukannya masalah yang dihadapi Widyasiswara BPSDM Provinsi DKI Jakarta dalam Penulisan Modul yaitu

1. Sistematika modul yang disusun belum disusun sesuai standarnya

2. Penulisan tujuan pembelajaran yang tidak sesuai standartnya.

3. Bahasa yang digunakan dalam modul belum komunikatif dan efektif.

4. Materi/sub materi yang dimasukkan tidak konsisten dengan tujuan pembelajaran atau materi pokok.

5. Kurangnya mengupdate referensi sumber buku yang terbaru

Pada dasarnya calon widyaiswara harus mendapatkan pelatihan mengenai penulisan modul, tetapi kenyataannya masih ada 
widyaiswara yang belum mendapatkan pelatihan secara khusus tentang penulisan modul. BPSDM Provinsi DKI memiliki keinginan untuk dapat mengembangkan pelatihan teknik menulis modul sendiri bagi Widyawaiswaranya untuk memperbaharui pengetahuan dan kompetensinya dalam menulis modul yang baik.

Berdasarkan beberapa masalah di atas, maka perlu adanya pendalaman terhadap pengetahuan dan kemampuan Widyaiswara dalam menulis modul yang baik. Maka intervensi dari masalah tersebut adalah mengembangkan suatu program pelatihan yang ditujukan kepada Widyaiswara BPSDM Provinsi DKI Jakarta untuk mengembangkan kompetensi dalam hal teknik penulisan modul yang baik dan benar. Hal ini dilandasi dengan tujuan pelatihan menurut Moekjizat (1991) yaitu antara lain:

1. Untuk mengembangkan keahlian, sehingga pekerjaan dapat diselesaikan dengan lebih cepat dan efektif

2. Untuk mengembangkan pengetahuan, sehingga pekerjaan dapat diselesaikan secara rasional

3. Untuk mengembangkan sikap, sehingga menimbulkan kemauan kerjasama dengan teman-teman pegawai dan manajemen (pimpinan)

\section{METODE}

Penelitian ini dilakukan melalui metode penelitian pengembangan instruksional yang bertujuan untuk menghasilkan program pelatihan. Dalam melakukan penelitian, peneliti menggunakan Model Pengembangan Instruksional (MPI) dari M. Atwi Suparman (2012)

Pengembangan program pelatihan ini didasarkan pada tahapan yang ada dalam model MPI, tahapan tersebut yaitu mengidentifikasi, mengembangkan, dan mengevaluasi dan merevisi.

\section{Tahap Mengidentifikasi}

1. Mengidentifikasi Kebutuhan Pembelajaran dan Menulis Tujuan Pembelajaran Umum

Langkah pertama dalam mendesain program pelatihan adalah mengidentifikasi kebutuhan pembelajaran. Langkah ini dilakukan untuk mengetahui kesenjangan yang terjadi pada peserta didik, baik pada aspek pengetahuan dan keterampilan. Untuk mengetahui kesenjangan tersebut, pengembang melakukan wawancara kepada Widyaiswara BPSDM Provinsi DKI Jakarta. Hasil yang di dapat dari kegiatan mengidentifikasi kebutuhan pembelajaran ialah diperolehnya jenis pengetahuan dan keterampilan yang belum dipelajari atau belum dilakukan oleh peserta didik. Dari hasil tersebut, pengembang dapat menentukan tujuan pembelajaran umum. Tujuan Pembelajaran Umum merupakan hasil belajar yang diharapkan dapat dikuasai peserta setelah mengikuti program pelatihan.

2. Melakukan Analisis Pembelajaran

Analisis pembelajaran merupakan proses yang berisi urutan kompetensi yang perlu dimiliki oleh peserta program pelatihan untuk

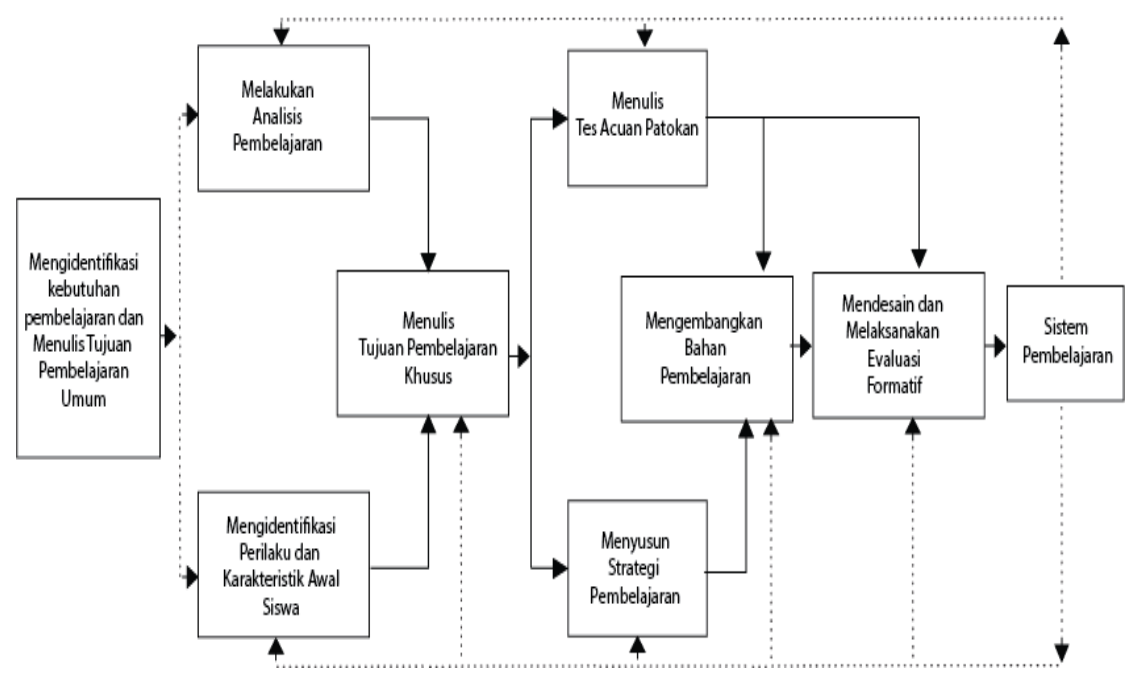

Gambar 1 Model Pengembangan Instruksional (MPI) 
mencapai tujuan pembelajaran umum. Dalam melakukan analisis pembelajaran ini, peneliti melakukan diskusi kepada ahli materi dan dosen pembimbing untuk menentukan pokok bahasan apa saja yang akan dibahas dalam pelatihan dan mengacu pada tujuan pembelajaran umum. Hasil dari langkah analisis instruksional adalah peta kompetensi dengan memilih pola peta kompetensi yang sesuai untuk pelatihan ini.

3. Mengidentifikasi Perilaku dan Karakteristik Awal Peserta Didik

Langkah ini sangat penting karena sebagai dasar dalam memilih pola pembelajaran yang sesuai untuk mengembangkan program pelatihan teknik penulisan modul yang sesuai untuk Widyaiswara BPSDM. Dalam mengidentifikasi perilaku dan karakteristik peserta pelatihan, peneliti melakukan wawancara kepada Widyaiswara.

\section{Tahap Mengembangkan}

4. Menulis Tujuan Pembelajaran Khusus (TIK)

Berdasarkan rumusan tujuan pembelajaran, hasil proses analisis instruksional dan hasil analisis karakteristik siswa, perancang program pelatihan dapat merumuskan tujuan pembelajaran khusus untuk pelatihan teknik penulisan modul untuk Widyaiswara. Dalam merumuskan tujuan pembelajaran umum ini peneliti melakukan diskusi dengan ahli materi untuk menghasilkan rumusan tujuan yang sesuai bagi program pelatihan ini. Untuk merumuskan tujuan pembelajaran khusus harus menggambarkan empat unsur yaitu $\mathrm{ABCD}$ (Audience, Behaviour, Condition, Degree) dan menggunakan kata kerja yang dapat diamati (observable) dan dapat diukur hasilnya (measurable).

\section{Menulis Tes Acuan Patokan}

Tes acuan patokan dimaksudkan untuk mengukur tingkat penguasaan setiap peserta didik terhadap perilaku yang tercantum dalam tujuan pembelajaran khusus. Pada langkah ini, pengembang menyusun bentuk tes yang sesuai mengukur ketercapaian tujuan pembelajaran khusus peserta didik setelah mengikuti program pelatihan ini dengan melakukan diskusi bersama ahli materi. Pada program pelatihan ini, pengembang memberikan tes kemampuan awal dan tes kemampuan akhir kepada peserta didik untuk mengetahui perbedaan hasil belajar yang dicapai sebelum dan sesudah mengikuti program pelatihan ini.

\section{Menyusun Strategi Pembelajaran}

Tahap selanjutnya ialah pengembang mulai menyusun strategi pembelajaran. Strategi pembelajaran berkaitan dengan menentukan pendekatan yang digunakan untuk menyampaikan isi materi kepada peserta didik. Dalam menyusun strategi pembelajaran, pengembang perlu melakukan diskusi dengan ahli disain pembelajaran dalam menentukan metode dan media pembelajaran apa saja serta berapa lama waktu pelatihan yang diperlukan, sehingga kompetensi yang diharapkan dapat dikuasai oleh peserta didik secara efektif dan efisien. Menyusun strategi pembelaaran dalam suatu program pelatihan meliputi empat komponen yaitu urutan kegiatan, metode, media dan waktu.

\section{Mengembangan Bahan Pembelajaran}

Pengembangan bahan pembelajaran ini mengacu pada bentuk kegiatan pembelajaran yang akan dilaksanakan dalam program pelatihan. Hal ini dimaksudkan agar bahan pembelajaran yang dikembangkan menjadi efektif digunakan selama proses pembelajaran berlangsung. Dalam pengembangan bahan pembelajaran ini, pengembang harus melakukan diskusi dengan ahli materi dan ahli media pembelajaranuntuk menghasilkan bahan ajar yang berkualitas dan memiliki kesesuaian dengan program pelatihan ini.

Bahan pembelajaran yang akan dikembangkan dalam program pelatihan ini, yaitu panduan bagi pengajar berupa kurikulum, bahan ajar mandiri bagi peserta didik berupa modul, dan media presentasi yang digunakan untuk proses pembelajaran program pelatihan penulisan modul untuk Widyaiswara BPSDM Provinsi DKI Jakarta.

\section{Tahap Mengevaluasi dan Merevisi}

8. Mendesain dan Melaksanakan Evaluasi Formatif.

Tahap selanjutnya yang dilakukan pengembang yaitu menyusun evaluasi formatif. Penyusunan instrument evaluasi dimaksudkan untuk menilai kualitas produk yang sedang dikembangkan. Pelaksanaan evaluasi program 
pelatihan ini dilakukan dengan dua tahapan evaluasi yaitu review ahli, dan evaluasi one-toone.

\section{HASIL DAN PEMBAHASAN}

Produk hasil yang dikembangkan dalam penelitian pengembangan ini adalah rancangan program pelatihan teknik penulisan modul untuk Widysaiswara BPSDM Provinsi DKI Jakarta. Pelatihan ini diekmbangkan berdarkan latar belakang kesenjangan serta kebutuhan yang ada, sehingga produk penelitian pengembangan ini menjadi intervensi dari kebutuhan tersebut. Pengembangan program pelatihan ini dikembangkan berdasarkan Model Pengembangan Instruksioan (MPI) yang melalui tiga tahapan besar yaitu mengidentifikasi, mengembangkan dan mengevaluasi dan merevisi.

\section{Tahap Mengidentifikasi}

1. Mengidentifikasi Kebutuhan Pembelajaran dan Menulis Tujuan Pembelajaran Umum

a. Tahap Identifikasi Kebutuhan

Tahap ini mulai dilakukan dengan melakukan wawancara. Pengembang, melakukan wawancara dengan Widyaiswara dan Pegawai Provinsi DKI Jakarta dibidang standarisasi dan penjaminan mutu.

Berikut kesimpulan wawancara dengan salah satu pegawai di BPSDM Provinsi DKI Jakarta dibidang standarisasi dan penjaminan mutu yaitu Ibu Tika Widya Agustina, bahwa modul yang dirancang sendiri oleh Widyaiswara BPSDM Provinsi DKI Jakarta masih kurang ideal. Ada beberapa modul yang belum sesuai dengan sistematika modul yang baik, bahasa yang digunakan dalam modul belum komunikatif dan banyaknya pengulangan kata. Selain itu masih kurangnya pemberian contoh dalam setiap materi yang dibahas, sehingga membuat materi tersebut bersifat abstrak. Selain itu, BPSDM belum memiliki suatu program untuk menunjang kinerja Widyaiswara dalam hal penulisan modul dikarenakan tidak adanya bidang yang dapat merancang dan mengembangkan program tersebut.

Peneliti juga melakukan wawancara dengan salah satu Widyaiswara BPSDM Provinsi DKI Jakarta yaitu Ibu Farihah memiliki kesulitan dalam menulis modul yaitu adanya perubahan pada pokok bahasan/mata diklat di dalam kurikulum, belum adanya panduan/program yang menjelaskan penulisan modul yang benar, kesulitan dalam menuliskan isi materi dengan bahasa yang komunikatif. Untuk menunjang keterampilan penulisan modul, Ibu Farihah saat hanya mengikuti pelatihan Karya Tulis Ilmiah saja. Belum mengikuti pelatihan secara khusus mengenai modul dan hanya berlatih menulis modul.

Berdasarkan hasil wawancara tersebut dapat disimpulkan sebagai berikut:

\section{1) Kondisi Sekarang :}

Beberapa Widyaiswara belum sepenuhnya memiliki pengetahuan dan kompetensi secara mendalam mengenai teknik penulisan modul, seperti perumusan tujuan pembelajaran (kompetensi dasar dan indikator keberhasilan) belum sesuai dengan standar. Selain itu isi materi yang dimasukkan tidak konsisten dengan tujuan pembelajaran, tidak menggunakan bahasa yang komunikatif, kurangnya kemampuan teknik mengutip dari referensi baik kutipan langsung atau tidak langsung dan kurang memperhatikan EYD serta masih terdapat modul yang sistematikanya belum sesuai standar penulisan modul diklat PNS.

2) Kondisi yang diharapkan:

Widyaiswara BPSDM Provinsi DKI Jakarta diharapkan memiliki pengetahuan dan kompetensi mengenai teknik penulisan modul yang sesuai dengan kaidah penulisan modul, sehingga menghasilkan modul yang komunikatif dan efektif sebagai bahan ajar diklat yang diselenggarakan di BPSDM.

\section{3) Kesenjangan :}

Berdasarkan data yang diperoleh melalui wawancara, terlihat bahwa adanya kesenjangan kinerja Widyaiswara. Kesenjangan tersebut ialah kurangnya keterampilan Widyaiswara dalam menulis modul sesuai standar serta kaidah-penulisan modul yang baik dan benar.

\section{4) Penyebab Kesenjangan}

Berdasarkan hasil wawancara dengan Widyaiswara dan pegawai BPSDM, penyebab kesenjangan tersebut ialah widyaiswara BPSDM sebagian besar belum memiliki pengetahuan dasar mengenai teknik penulisan modul yang 
sesuai dengan kaidah dan standar yang seharusnya. Hal tersebut disebabkan karena tidak adanya panduan/program yang mendukung secara khusus untuk memberikan pengetahuan dan meningkatkan kompetensi menulis modul bagi Widyaiswara dari BPSDM Provinsi DKI Jakarta sendiri.

Dari hasil wawancara bahwa mereka belum mengikuti pelatihan yang secara khusus mempelajari teknik penulisan modul yang baik dan benar.

\section{b. Menulis Tujuan Pembelajaran Umum}

Tujuan pembelajaran umum dalam program pelatihan ini mengacu pada hasil identifikasi kebutuhan pelatihan di atas, adalah:

"Setelah mengikuti pelatihan ini, peserta diharapkan mampu menulis modul diklat sesuai standar serta kaidah-penulisan modul yang baik dan benar".

\section{Melakukan Analisis Pembelajaran}

Peneliti menggunakan pola kombinasi yang terdiri dari pola hierarki dan cluster. Peneliti memilih pola kombinasi karena adanya pengetahuan sebelumnya menjadi prasyarat yang harus dimiliki oleh peserta, sebelum dia mampu untuk menguasai keterampilan selanjutnya dan ada beberapa kemampuan yang satu dengan lainnya tidak memiliki ketergantungan tetapi harus dimiliki secara lengkap untuk mencapai tujuan pelatihan. Berikut ini adalah bagan pola/peta kompetensi mata pelatihan teknik penulisan modul untuk Widyaiswara di BPSDM Provinsi DKI Jakarta.
3. Mengidentifikasi Perilaku dan Karakteristik Awal Peserta Didik

Langkah ini sangat penting karena sebagai dasar dalam memilih pola pembelajaran yang sesuai untuk mengembangkan program pelatihan teknik penulisan modul yang sesuai untuk Widyaiswara BPSDM. Dalam mengidentifikasi perilaku dan karakteristik peserta pelatihan, peneliti melakukan wawancara kepada dua Widyaiswara BPSDM Provinsi DKI Jakarta.

Berikut hasil wawancara pengembang dengan penulis modul dan editor modul BPSDM Provinsi DKI Jakarta.

\section{a. Karakteristik Peserta Didik}

Widyaiswara BPSDM Provinsi DKI Jakarta memiliki latarbelakang pendidikan yang beragam dengan jenjang pendidikan mulai dari S1 hingga $\mathrm{S}_{3}$ dan rentang usia berkisar 30-50 tahun sehingga sudah memiliki banyak pengalaman menjadi pengajar di berbagai lembaga. Proses untuk menjadi widyaiswara pun beragam, ada yang berasal dari guru, kepala sekolah atau wakil kepala sekolah hingga yang sudah memiliki jenjang kepangkatan eselon.

Widyaiswara BPSDM memiliki motivasi untuk selalu belajar sehingga menambah pengetahuan mereka dalam bidangnya. Widyaiswara berkeinginan agar BPSDM DKI Jakarta dapat memberikan program yang dapat menambah pengetahuan dan kompetensinya, dalam hal ini mengenai penulisan modul yang baik dan benar sehingga mereka dapat menghasilkan modul yang berkualitas bagi diklat di BPSDM Provinsi DKI Jakarta.

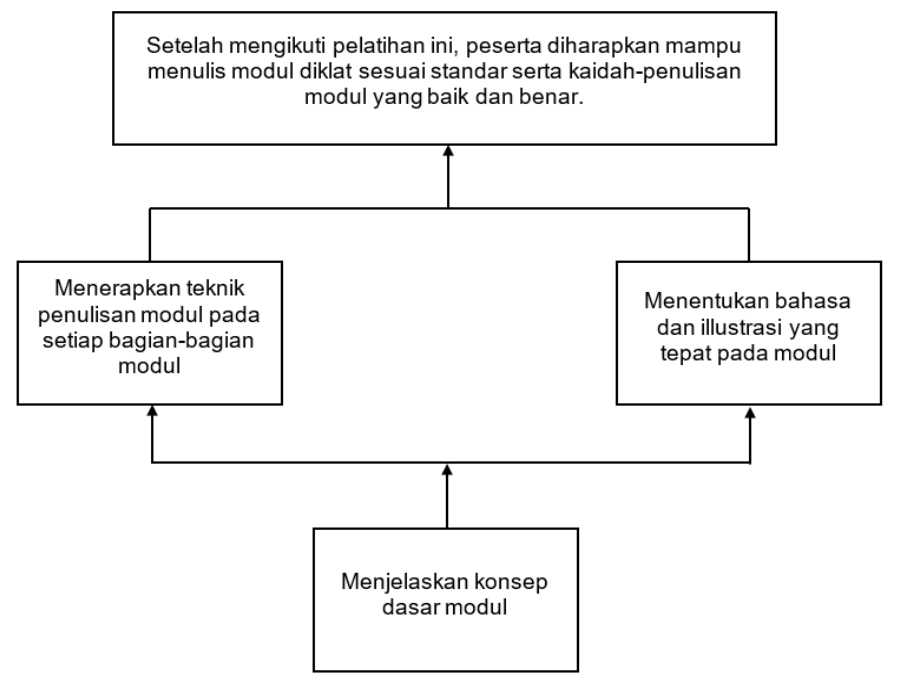

Gambar 2 Peta Kompetensi Pelatihan Teknik Penulisan Modul 
b. Kemampuan

Tabel 1 Kemampuan Awal

\begin{tabular}{|c|c|c|}
\hline No & Aspek & $\begin{array}{c}\text { Hasil } \\
\text { Wawancara }\end{array}$ \\
\hline 1 & Peserta Didik & $\begin{array}{l}\text { Widyaiswara } \\
\text { BPSDM Provinsi } \\
\text { DKI Jakarta }\end{array}$ \\
\hline 2 & $\begin{array}{l}\text { Pengetahuan yang } \\
\text { sudah dimiliki }\end{array}$ & $\begin{array}{l}\text { Memiliki } \\
\text { pengetahuan } \\
\text { mengenai } \\
\text { pengembangan } \\
\text { modul secara } \\
\text { umum, tetapi } \\
\text { pada } \\
\text { kenyataannya } \\
\text { belum } \\
\text { sepenuhnya } \\
\text { menghasilkan } \\
\text { modul yang } \\
\text { sesuai kaidah } \\
\text { teknik penulisan } \\
\text { modul. } \\
\end{array}$ \\
\hline 3 & $\begin{array}{l}\text { Kemampuan } \\
\text { menulis modul }\end{array}$ & $\begin{array}{l}\text { Kemampuan } \\
\text { menulis modul } \\
\text { hanya dipelajari } \\
\text { sendiri saja } \\
\text { dengan banyak } \\
\text { berlatih menulis } \\
\text { dan membaca. }\end{array}$ \\
\hline
\end{tabular}

\section{Tahap Mengembangkan}

4. Menulis Tujuan Pembelajaran Khusus

Berdasarkan rumusan tujuan pembelajaran, hasil proses analisis instruksional dan hasil analisis karakteristik siswa, perancang program pelatihan dapat merumuskan tujuan pembelajaran khusus untuk pelatihan teknik penulisan modul untuk Widyaiswara.

Maka rumusan tujuan pembelajaran khusus yang dianggap sesuai untuk program ini, antara lain:

a. Setelah mengikuti program pelatihan ini, widyaiswara dapat menjelaskan hakikat modul minimal 80\% dengan benar.

b. Setelah mengikuti program pelatihan ini, widyaiswara dapat menerapkan teknik penulisan modul pada setiap bagian-bagian modul dengan benar.

c. Setelah mengikuti program pelatihan ini, widyaiswara dapat menentukan bahasa dan illustrasi yang tepat dalam modul.

\section{Menulis Tes Acuan Patokan}

Dalam pengembangan program pelatihan ini, tes acuan patokan akan diberikan kepada peserta pelatihan berupa tes kemampuan awal (pretest) dan tes kemampuan akhir (postest). Hal tersebut dilakukan untuk mengetahui perbedaan hasil belajar yang dicapai oleh peserta pelatihan saat sebelum dan sesudah mengikuti pelatihan.

Peneliti mengembangan kisi-kisi tes acuan dan soal pretest dan postest yang sudah dikembangkan berdasarkan kisi-kisi sebelumnya dengan jumlah soal 20.

Tabel 2 Kisi-kisi Tes Acuan Patokan

\begin{tabular}{|c|c|c|c|c|c|}
\hline \multirow[b]{2}{*}{$\begin{array}{c}\text { Kompet } \\
\text { ensi } \\
\text { Dasar }\end{array}$} & \multirow[b]{2}{*}{$\begin{array}{l}\text { Keg. } \\
\text { Belajar }\end{array}$} & \multirow[b]{2}{*}{ Indikator } & \multirow[b]{2}{*}{$\begin{array}{l}\text { Jenjang } \\
\text { Kognitif }\end{array}$} & \multicolumn{2}{|c|}{$\begin{array}{c}\text { Klasifikasi } \\
\text { Soal }\end{array}$} \\
\hline & & & & $\begin{array}{l}\text { Bent } \\
\text { uk } \\
\text { Soal }\end{array}$ & $\begin{array}{l}\text { No } \\
\text { So } \\
\text { al }\end{array}$ \\
\hline \multirow{7}{*}{$\begin{array}{l}\text { Widyais } \\
\text { wara } \\
\text { dapat } \\
\text { menjela } \\
\text { skan } \\
\text { hakikat } \\
\text { modul } \\
\text { minima } \\
180 \% \\
\text { dengan } \\
\text { benar. }\end{array}$} & \multirow{7}{*}{$\begin{array}{l}\text { Konsep } \\
\text { Dasar } \\
\text { Modul }\end{array}$} & \multirow{2}{*}{$\begin{array}{l}\text { Mampu } \\
\text { menjelaskan } \\
\text { konsep } \\
\text { modul }\end{array}$} & $\mathrm{C}_{1}$ & PG & 1 \\
\hline & & & $\mathrm{C}_{2}$ & PG & 2 \\
\hline & & \multirow{3}{*}{$\begin{array}{l}\text { Mampu } \\
\text { menjelaskan } \\
\text { fungsi modul }\end{array}$} & $\mathrm{C}_{1}$ & PG & 3 \\
\hline & & & $\mathrm{C}_{2}$ & PG & 4 \\
\hline & & & $\mathrm{C}_{2}$ & PG & 5 \\
\hline & & \multirow{2}{*}{$\begin{array}{l}\text { Mampu } \\
\text { mengidentifik } \\
\text { asi sistematika } \\
\text { modul }\end{array}$} & $\mathrm{C}_{2}$ & PG & 6 \\
\hline & & & $\mathrm{C}_{2}$ & PG & 7 \\
\hline \multirow{8}{*}{$\begin{array}{l}\text { Widyais } \\
\text { wara } \\
\text { dapat } \\
\text { menera } \\
\text { pkan } \\
\text { teknik } \\
\text { penulis } \\
\text { an } \\
\text { modul } \\
\text { sesuai } \\
\text { kaidah } \\
\text { yang } \\
\text { benar }\end{array}$} & \multirow{8}{*}{$\begin{array}{l}\text { Teknik } \\
\text { Penulis } \\
\text { an Isi } \\
\text { Modul }\end{array}$} & \multirow{2}{*}{$\begin{array}{l}\text { Mampu } \\
\text { menjelaskan } \\
\text { definisi tujuan } \\
\text { pembelajaran }\end{array}$} & $\mathrm{C}_{1}$ & PG & 8 \\
\hline & & & $\mathrm{C}_{2}$ & PG & 9 \\
\hline & & \multirow{2}{*}{$\begin{array}{l}\text { Mampu } \\
\text { menentukan } \\
\text { unsur-unsur } \\
\text { dalam tujuan } \\
\text { pembelajaran }\end{array}$} & $\mathrm{C}_{2}$ & PG & 10 \\
\hline & & & $\mathrm{C}_{2}$ & PG & 11 \\
\hline & & \multirow[b]{2}{*}{$\begin{array}{l}\text { Mampu } \\
\text { mengidentifik } \\
\text { asi cara } \\
\text { penulisan } \\
\text { modul pada } \\
\text { bagian } \\
\text { pendahuluan }\end{array}$} & $\mathrm{C}_{2}$ & PG & 12 \\
\hline & & & $\mathrm{C}_{2}$ & PG & 13 \\
\hline & & $\begin{array}{l}\text { Mampu } \\
\text { mengidentifik } \\
\text { asi cara } \\
\text { penulisan } \\
\text { modul pada } \\
\text { bagian uraian } \\
\text { modul } \\
\end{array}$ & $\mathrm{C}_{2}$ & PG & 14 \\
\hline & & $\begin{array}{l}\text { Mampu } \\
\text { mengidentifik } \\
\text { asi cara } \\
\text { penulisan } \\
\text { evalusi pada } \\
\text { bagian } \\
\text { penutup } \\
\text { modul } \\
\end{array}$ & $\mathrm{C}_{2}$ & PG & 15 \\
\hline \multirow[b]{2}{*}{$\begin{array}{l}\text { Widyais } \\
\text { wara } \\
\text { dapat } \\
\text { menera } \\
\text { pkan } \\
\text { bahasa } \\
\end{array}$} & \multirow{2}{*}{$\begin{array}{l}\text { Bahasa } \\
\text { dan } \\
\text { Illustras } \\
\text { i dalam } \\
\text { Modul }\end{array}$} & \multirow{2}{*}{$\begin{array}{l}\text { Mampu } \\
\text { membandingk } \\
\text { an gaya } \\
\text { Bahasa } \\
\text { percakapan } \\
\text { yang } \\
\end{array}$} & $\mathrm{C}_{2}$ & PG & 16 \\
\hline & & & $\mathrm{C}_{2}$ & PG & 17 \\
\hline
\end{tabular}


Putri Purwaning | JPI/Vol.o2/No.02/2019| H. 106-115

\begin{tabular}{|l|l|l|l|l|l|}
\hline $\begin{array}{l}\text { dan } \\
\text { illustras } \\
\text { i yang } \\
\text { tepat } \\
\text { dalam } \\
\text { modul. }\end{array}$ & $\begin{array}{l}\text { digunakan } \\
\text { dalam modul }\end{array}$ & & & \\
\cline { 2 - 5 } & & $\begin{array}{l}\text { Mampu } \\
\text { mengidentifik } \\
\text { asi } \\
\text { penggunaan } \\
\text { tanda baca } \\
\text { yang } \\
\text { digunakan } \\
\text { dalam modul }\end{array}$ & & PG & 18 \\
\hline $\begin{array}{l}\text { Mampu } \\
\text { membandingk } \\
\text { an tata cara } \\
\text { penulisan } \\
\text { kutipan yang } \\
\text { benar }\end{array}$ & C2 & PG & 19 \\
\hline $\begin{array}{l}\text { Mampu } \\
\text { mengkategori } \\
\text { kan illustrasi } \\
\text { pada isi } \\
\text { modul }\end{array}$ & C2 & PG & 20 \\
\hline
\end{tabular}

6. Menyusun Strategi Pembelajaran

Penyusunan strategi pembelajaran untuk suatu program pelatihan harus disesuaikan dengan kondisi peserta didik dan materi apa yang akan disampaikan. Menyusun strategi pembelajaran dalam suatu program pelatihan meliputi empat komponen yaitu urutan kegiatan pembelajaran, metode pembelajaran, media pembelajaran dan waktu.

Strategi pembelajaran untuk program pelatihan teknik penulisan modul yang terdiri dari tujuan pembelajaran khusus, pokok bahasan, urutan kegiatan pembelajaran (kegiatan pendahuluan, kegiatan penyajian dan kegiatan penutup), metode, media yang digunakan dan perkiraan waktu yang akan dilaksanakan.

7. Mengembangkan Bahan Pembelajaran

Bahan pembelajaran yang dikembangkan dalam program pelatihan ini, yaitu panduan bagi penyelenggara atau instruktur berupa kurikulum, bahan ajarmandiri bagi peserta didik berupa modul, dan media presentasi yang digunakan untuk proses pembelajaran program pelatihan teknik penulisan modul untuk Widyaiswara BPSDM Provinsi DKI Jakarta.

a. Buku Program Pelatihan (Kurikulum)

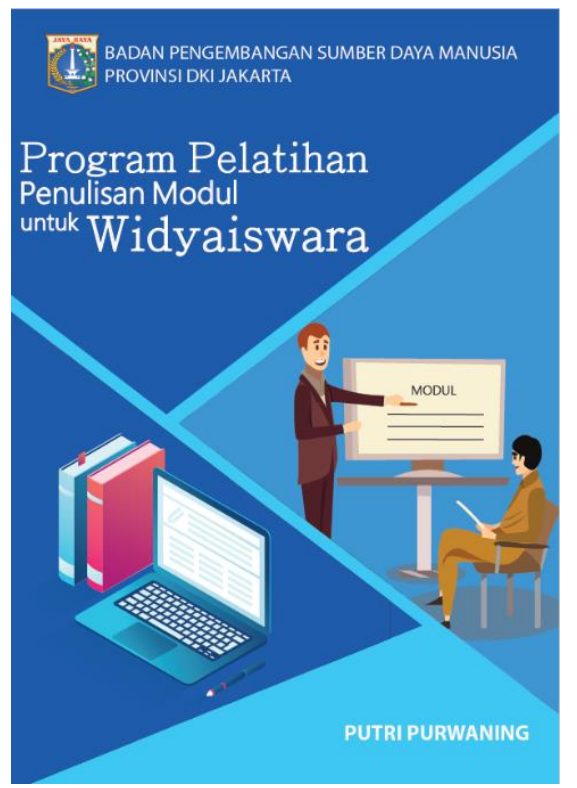

\section{Gambar 4 Buku Program Pelatihan}

Rancangan program pelatihan ini diberikan kepada penyelenggara dan instruktur, sebagai pedoman dalam penyelenggaraan

STRATEGI PEMBELAJARAN

TPK 1

Materi Konsep Dasar Modul

\begin{tabular}{|c|c|c|c|c|c|c|c|}
\hline \multirow{2}{*}{$\begin{array}{c}\text { Tujuan } \\
\text { Instruksional } \\
\text { Khusus }\end{array}$} & \multirow{2}{*}{$\begin{array}{c}\text { Pokok } \\
\text { Bahasan }\end{array}$} & \multicolumn{6}{|c|}{ Strategi Pembelajaran } \\
\hline & & \multicolumn{2}{|c|}{ Urutan Kegiatan Pembelajaran } & Metode & Media & Estimasi & Pustaka \\
\hline \multirow{2}{*}{$\begin{array}{l}\text { Setelah } \\
\text { mengikuti } \\
\text { program } \\
\text { pelatihan ini, } \\
\text { widyaiswara } \\
\text { dapat } \\
\text { menjelaskan } \\
\text { konsep dasar } \\
\text { modul minimal } \\
80 \% \text { dengan } \\
\text { benar. }\end{array}$} & \multirow[t]{2}{*}{$\begin{array}{l}\text { Konsep } \\
\text { Dasar } \\
\text { Modul }\end{array}$} & $\begin{array}{l}\text { Pemberian } \\
\text { tes awal } \\
\text { (Pretest) }\end{array}$ & $\begin{array}{l}\text { Deskripsi Singkat : } \\
\text { Sebelum proses } \\
\text { pembelajaran } \\
\text { dimulai, pengajar } \\
\text { akan memberikan tes } \\
\text { awal berupa pretest } \\
\text { untuk mengetahui } \\
\text { pengetahuan atau } \\
\text { kemampuan awal } \\
\text { peserta didik. }\end{array}$ & $\begin{array}{l}\text { Pretest hanya } \\
\text { diberikan } \\
\text { sekali pada } \\
\text { awal } \\
\text { mulainya } \\
\text { pelatihan }\end{array}$ & $\begin{array}{l}\text { Lembar } \\
\text { soal tes } \\
\text { awal } \\
\text { (pretest) }\end{array}$ & 10 & \multirow[t]{2}{*}{$\begin{array}{l}\text { Modul } \\
\text { Pelatihan } \\
\text { Teknik } \\
\text { Penulisan } \\
\text { modul untuk } \\
\text { Widyaiswara } \\
\text { BPSDM } \\
\text { Provinsi DKI } \\
\text { Jakarta }\end{array}$} \\
\hline & & & $\begin{array}{l}\text { Deskripsi Singkat: } \\
\text { Materi ini akan } \\
\text { mempelajari } \\
\text { mengenai hakikat } \\
\text { secara dalam, mulai } \\
\text { dari pengertian, }\end{array}$ & $\begin{array}{l}\text { Memberikan } \\
\text { penjelasan } \\
\text { secara } \\
\text { deskriptif } \\
\text { dilengkapi }\end{array}$ & $\begin{array}{l}\text { Penjelasan } \\
\text { slide } \\
\text { power } \\
\text { point }\end{array}$ & 10 & \\
\hline
\end{tabular}

Gambar 3 Strategi Pembelajaran Materi 1 Konsep Dasar Modul 
pelatihan. Panduan program pelatihan berbentuk buku cetak dengan ukuran $\mathrm{B}_{5}$ yang di dalamnya tertera prosedur penyelenggaran pelatihan yang didalamnya terdapat kurikulum pelatihan yang terdiri atas landasan pelatihan, analisis kurikuler, mata pelatihan, ruang lingkup program pelatihan, penyelenggaraan, alur proses pembelajaran, garis besar program pelatihan (GBPP), metode pembelajaran, alat bantu dan sarana prasarana hingga evaluasi.

Pihak penyelenggara maupun instruktur harus membaca dan memahami isi dari kurikulum, serta mengaplikasikan prosedur penyelenggaraan yang dijelaskan. Dengan begitu, kegiatan pelatihan yang telah dirancang dapat dilaksanakan dengan terorganisir.

\section{b. Bahan Pelatihan}

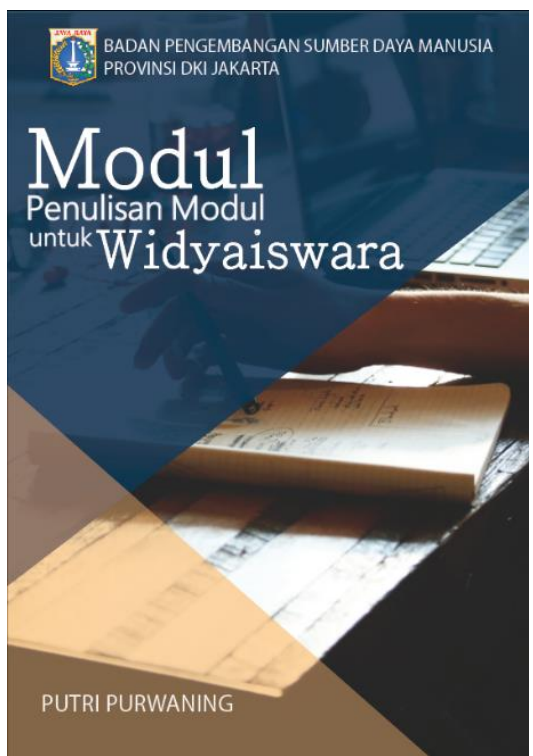

Gambar 5 Modul Pelatihan Teknik Penulisan Modul

Bahan pelatihan yang dikembangkan pada program pelatihan ini berupa modul yang dapat digunakan secara mandiri oleh peserta pelatihan. Bahan pelatihan ini berisikan materimateri yang disusun berdasarkan kebutuhan peserta dan diskusi dengan ahli materi dan gabungan dari beberapa sumber yang kemudian diolah oleh pengembang menggunakan bahasa yang mudah dimengerti dan sesuai karakteristik peserta.

Modul pelatihan ini berisi pendahuluan, tiga kegiatan belajar yang terdiri dari uraian; latihan; rangkuman; tes formatif dan umpan balik dan tindak lanjut, serta bagian pendukung lainnya. Pengemasan modul dalam bentuk buku cetak berukuran $\mathrm{A}_{4}$ dengan alasan menyesuaikan karakteristik Widyaiswara BPSDM Provinsi DKI Jakarta.

c. Media Pembelajaran

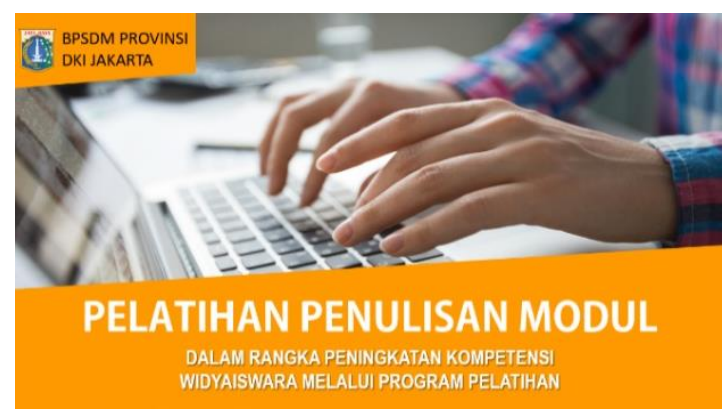

Gambar 6 Media Presentasi Program Pelatihan Teknik Penulisan Modul

Media pelatihan dalam pelatihan ini adalah slide presentasi yang berupa power point yang berisi inti dari materi pada modul pelatihan pada. Media pelatihan ini berguna untuk membantu instruktur dalam menyampaikan materi pelatihan secara singkat. Agar lebih menarik bagi peserta, slide presentasi ini disertai gambar visual dan warna yang menarik.

\section{Tahap Mengevaluasi dan Melaksanakan Revisi}

8. Mendesain dan Melaksanakan Evaluasi Fornatif

Dalam evaluasi formatif pengembang hanya melakukan dua tahapan yaitu review ahli yang terdiri dari ahli disain pembelajaran dengan hasil nilai 3,73 yang menunjukkan kriteria sangat baik, ahli materi dengan hasil nilai 3,82 yang menunjukkan sangat baik, dan ahli media pembelajaran untuk modul dengan hasil nilai 3,88 yang menunjukkan sangat baik dan untuk media PPT dengan hasil nilai 3,17 yang menunjukkan baik. Evaluasi one to one kepada tiga responden widyaiswara dengan hasil nilai 3 yang menunjukkan baik.

\section{SIMPULAN}

Penelitian pengembangan ini menghasilkan sebuah program pelatihan yang dirancang dengan menggunakan Model Pengembangan Instruksional (MPI). Program pelatihan ini bertujuan untuk meningkatkan kompetensi Widyaiswara BPSDM Provinsi DKI Jakarta dalam penulisan modul. Secara umum 
hasil penelitian ini ditunjukkan dengan hasil evaluasi formatif produk yang dikategorikan baik melalui expert review dan ujicoba one to one. Namun penelitian ini memiliki kekurangan yaitu tidak melakukan uji lapangan sehingga tidak mengetahui penerapan program pelatihan di lapangan dalam keadaan nyata.

\section{UCAPAN TERIMA KASIH}

Segala puji dan syukur penulis panjatkan kepada Allah SWT atas kasih dan rahmat-Nya penulis dapat menyelesaikan jurnal ini. Penulis mengucapkan terima kasih kepada semua staff dan dosen Program Studi Teknologi Pendidikan yang telah banyak berjasa kepada penulis selama berkuliah di UNJ, terima kasih atas ilmunya. Penulis ingin berterima kasih khususnya kepada dosen pembimbing I yaitu Ibu Retno Widyaningrum dan dosen pembimbing II yaitu Bapak Cecep Kustandi yang telah meluangkan waktu, pikiran dan tenaga serta dengan sabar membimbing dan mengarahkan penulis dalam menyelesaikan skripsi ini. Penulis ucapkan terima kasih kepada pihak Pengembangan Sumber Daya Manusia Provinsi DKI Jakarta yaitu Ibu Budihastuti selaku Kepala Badan Pengembangan Sumber Daya Manusia Provinsi DKI Jakarta yang telah memberi ijin Penulis untuk melakukan penelitian di BPSDM Provinsi DKI Jakarta. Penulis juga mengucapkan terima kasih kepada Ibu Tika Agustina yang sudah membimbing dan membantu Penulis. Tidak lupa juga penulis ingin berterima kasih pada Ibu Farihah dan Ibu Imah selaku Widyaiswara BPSDM Provinsi DKI Jakarta yang telah meluangkan waktu padatnya untuk memberikan informasi dan masukan terhadap skripsi ini. Penulis ingin berterima kasih kepada Ibu Diana Ariani, Bapak Robinson Situmorang, dan Bapak Kunto Imbar yang telah meluangkan waktunya untuk melakukan expert review. Terima kasih atas jasa print Mahkota yang telah memberikan jasa untuk mencetak produk saya.

\section{DAFTAR PUSTAKA}

Anwar, Ilham. 2010. Pengembangan Bahan Ajar: Bahan Kuliah Online. Bandung: Direktorat UPI

Hamalik, Oemar. 2011. Kurikulum dan Pembelajaran. Jakarta: Bumi Aksara.
Hasibuan, Melayu, S., P. 2017. Manajemen Sumber Daya Manusia. Edisi Revisi. Jakarta: PT Bumi Aksara

Moekijat. 1991. Latihan dan Pengembangan Sumber Daya Manusia. Bandung: Penerbit Bandar Maju

Peraturan Kepala Lembaga Administrasi Negara Nomor. 5 Tahun 2009. Tentang Pedoman Penulisan Pendidikan dan Pelatihan

Peraturan Menteri Pendayagunaan Aparatur Negara dan Reformasi Birokrasi RI No. 22 Tahun 2014. Tentang Jabatan Fungsional Widyaiswara dan Angka Kreditnya

Purwanto, Aristo, dan Suharto. 2007. Pengembangan Modul. Jakarta: PUSTEKOM

Sitepu, B.P. 2006. Penyusunan Buku Pelajaran. Jakarta: Verbum Publishing.

Suparman, Atwi. 2012. Desain Instruksional Modern: Panduan Para Pengajar dan Inovator Pendidikan. Jakarta: Erlangga 